\title{
Development of successive cambia and structure of the secondary xylem in some members of the family Amaranthaceae
}

\author{
Ravindra A. Shelke ${ }^{1}$, Dhara G. Ramoliya ${ }^{2}$, Amit D. Gondaliya ${ }^{2}$ and Kishore S. Rajput ${ }^{2^{*}}$ \\ ${ }^{1}$ Kisan Arts, Commerce and Science College, Parola 425 111, Maharashtra, India \\ ${ }^{2}$ Department of Botany, Faculty of Science, The Maharaja Sayajirao University of Baroda; Vadodara - 390 002, Gujarat, India
}

\section{Article history}

Received: 09 October 2018 Accepted: 02 January 2019

Published: 16 January 2019

\section{Editor}

Dr Sheikh Muhammad Masum Sher-e-Bangla Agricultural University

Bangladesh

\section{Publisher}

Horizon e-Publishing Group

\author{
*Correspondence \\ Kishore S. Rajput \\ 凶ks.rajput@yahoo.com
}

\begin{abstract}
Young stems of Aerva javanica (Burm.f.) Juss. ex Schult., A. lanata (L.) Juss. ex Schult, A. monsonia Mart., A. sanguinolenta (L.) Blume, Alternanthera bettzickiana (Regel) G. Nicholson, A. philoxeroides (Mart.) Griseb., Gomphrena celosioides Mart., G. globosa L. and Telanthera ficoidea (L.) Moq., showed the renewal of small sectors of cambium by replacing with new segments. Therefore, the secondary phloem formed by earlier cambial segments form isolated islands of phloem enclosed within conjunctive tissues became embedded in the secondary xylem. As the stem grows older, complete ring of cambium is renewed; sometimes an anastomosing network of successive cambia may be seen due to the renewal of larger segments of the cambium. Renewal of the cambium takes place by repeated periclinal division in the parenchyma cells positioned outside to the phloem formed by the previous cambium. Functionally the cambium is bidirectional and exclusively composed of fusiform cambial cells. Differentiation of conducting elements of the secondary xylem and phloem remains restricted to the certain cambial cells while rest of the segments exclusively produce conjunctive cells. Accumulation of starch along with the presence of nuclei in the xylem fibers even after deposition of the secondary wall is consistent in all the species and it seems to be associated with the absence of rays in the secondary xylem and phloem of nine species from four genera. The significance of successive cambia, rayless xylem and nucleated xylem fibers were correlated with plant habit.
\end{abstract}

Keywords: Nucleated fibers; rayless xylem; successive cambia

\section{Citation}

Shelke RA, Ramoliya DG, Gondaliya AD, Rajput KS. Development of successive cambia and structure of the secondary xylem in some members of the family Amaranthaceae. Plant Science Today 2019;6(1):3139. https://doi.org/10.14719/pst.2019.6.1.423

Copyright: (C) Shelke et al. (2019). This is an open-access article distributed under the terms of the Creative Commons Attribution License, which permits unrestricted use, distribution, and reproduction in any medium, provided the original author and source are credited (https://creativecommons.org/licenses/by/4.0/).

Indexing: Plant Science Today is covered by Scopus, CAS, AGRIS, CABI, Google Scholar, etc. Full list at http://www.plantsciencetoday.online

\section{Introduction}

Families like Amaranthaceae, Chenopodiaceae, Nyctaginaceae, Phytolccaceae etc. from the core Caryophyllales are well recognized in literature for their unique pattern of secondary growth. Development of successive cambia takes place from the parenchymatous cells positioned outside to the primary phloem of each vascular bundle. An 
opinion regarding the origin of successive cambia, structure and composition of its derivatives varies among different workers (1-10). Therefore, nearly 65 synonyms are reported to be available in the literature (11) on the meristem on this group.

According to De Bary
Amaranthaceae the in
permanently active throughout the year, while Wilson (2) documented it to be constantly renewed. Schinz (3) mentioned that an increase in stem diameter and production of secondary vascular tissue in Amaranthaceae takes place by successive cambia that divide for a limited period. In contrast, Mao (12) disagreed with Schinz (3) and reported that supernumerary cambia of this family are continuously renewed from a cambium that divides indefinitely. Balfour (4) examined some members from the families like Chenopodiaceae, Nyctaginaceae, and Amaranthaceae and concluded that the occurrence of cambial variant (i.e. supernumerary cambia) is a constant feature in these families. According to Balfour (4) initiation of these cambia is inconsistent and may originate from semi-mature cells of the cortex, or from the meristematic cells. These cells may be in contact with a regular (normal) cambium or may be located external to the phloem.

Stevenson and Popham (5) compared this growth pattern with monocotyledons and proposed a new term as "primary thickening meristem (PTM)". DeMason (6) disagreed with the Stevenson and Popham (5) regarding the application of term PTM in dicotyledons because PTM along with an apical meristem forms a primary plant body while vascular cambium produces secondary vascular tissues. Menezes et al. (13) proposed a new interpretation of the term PTM. According to them PTM includes pericycle, endodermis and its immediate derivatives (or only the pericycle). Beside these, various terms like diffuse lateral meristem (14), confined meristem (15), lateral meristem (16) can be also found in the literature for the cambium of families of core caryophyllales. Carlquist $(9,10)$ reinvestigated the development of successive cambia in Amaranthaceae and its allied families and proposed a new term "master cambium" to the meristem leading to the development of successive cambia. Despite several publications, each investigation was concentrated on the nature and origin of the meristem leading to an increase in stem thickness of the species. Information on xylem structure of some species is documented partially or lacking totally. For instance, presence of nuclei in the xylem fibres and development of rays in the later stage of secondary growth.

Due to the difference of opinions, several species of Amaranthaceae have been investigated anatomically to understand the growth pattern and structure of secondary xylem $(7-10,16,17)$ while information on some of them is either meagre or totally lacking. Rajput (7) described the structure of the secondary xylem and development of successive cambia in 5-8 $\mathrm{mm}$ thick stems of $A$. lanata, A. sanguinolenta, Gomphrena celosioides and Telanthera ficoidea while stem anatomy of Aerva javanica, A. monsonia, Alternanthera bettzickiana and $A$. philoxeroides is described for the first time. In the present study, samples of $A$. lanata, A. sanguinolenta, Gomphrena celosioides and Telanthera ficoidea were reinvestigated from the fully-grown individuals having stem diameter $3-20 \mathrm{~mm}$ (fully grown term refers to plants collected at the end of the growing season). The reason is to know whether rays develop in thick stems or not because Carlquist (8) mentioned that none of the species in Amaranthaceae is rayless. In contrast, Fig. 3A in the present study is similar to Fig. 8 shown by Carlquist (10) for Heimerliodendron brunonianum (Nyctaginaceae) in which, Fig. 8 is labelled as rayless xylem. From our earlier study $(7,18,19)$, it is very well demonstrated that the xylem in some species of Amaranthaceae remains rayless in the early stages of secondary growth (young stems) and they develop in the later part of the secondary growth in thick stems. Sometimes, the occurrence of radial plates of axial parenchyma that appear like rays in transverse view has been observed in many species and this feature has been reported in Amaranthaceae and its allied families (20). Therefore, the main aim of the present study was to reinvestigate the structure of secondary xylem in species which are not studied earlier by including fully-grown (thick) stems of those species that are investigated previously.

\section{Materials and Methods}

Four to eight internodal segments from the main stem were collected from five individual each of Aerva javanica (Burm.f.) Juss. ex Schult., A. lanata (L.) Juss., A. monsonia Mart., A. sanguinolenta (L.) Blume, Alternanthera bettzickiana (Regel) G. Nicholson, A. philoxeroides (Mart.) Griseb., Gomphrena celosioides Mart. and Telanthera ficoidea Moq. (Amaranthaceae). All the specimens were collected from the plants growing wild in natural habitats at Dinodhar (Kutchh), Ramson (North Gujarat), Dediapada (central Gujarat), Dang Forest (South Gujarat) and Arboretum of The Maharaja Sayajirao University of Baroda, Vadodara except Telanthera ficoidea was under cultivation. The stem portions, $5 \mathrm{~cm}$ above the ground level and as thick as available (3-20 $\mathrm{mm}$ for Aerva species and 8-12 $\mathrm{mm}$ for Alternanthera, Gomphrena, and Telanthera) were cut into 5-6 cm long pieces and immediately fixed in FAA (Formaldehyde - Acetic acid - Alcohol) (21). Herbarium specimens were submitted to BARO herbarium of the Department of Botany, The M. S. University of Baroda, Vadodara. After $24 \mathrm{hrs}$ of fixation, pieces of young stems were trimmed into 2-3 $\mathrm{mm}$ transverse discs, dehydrated in TBA 

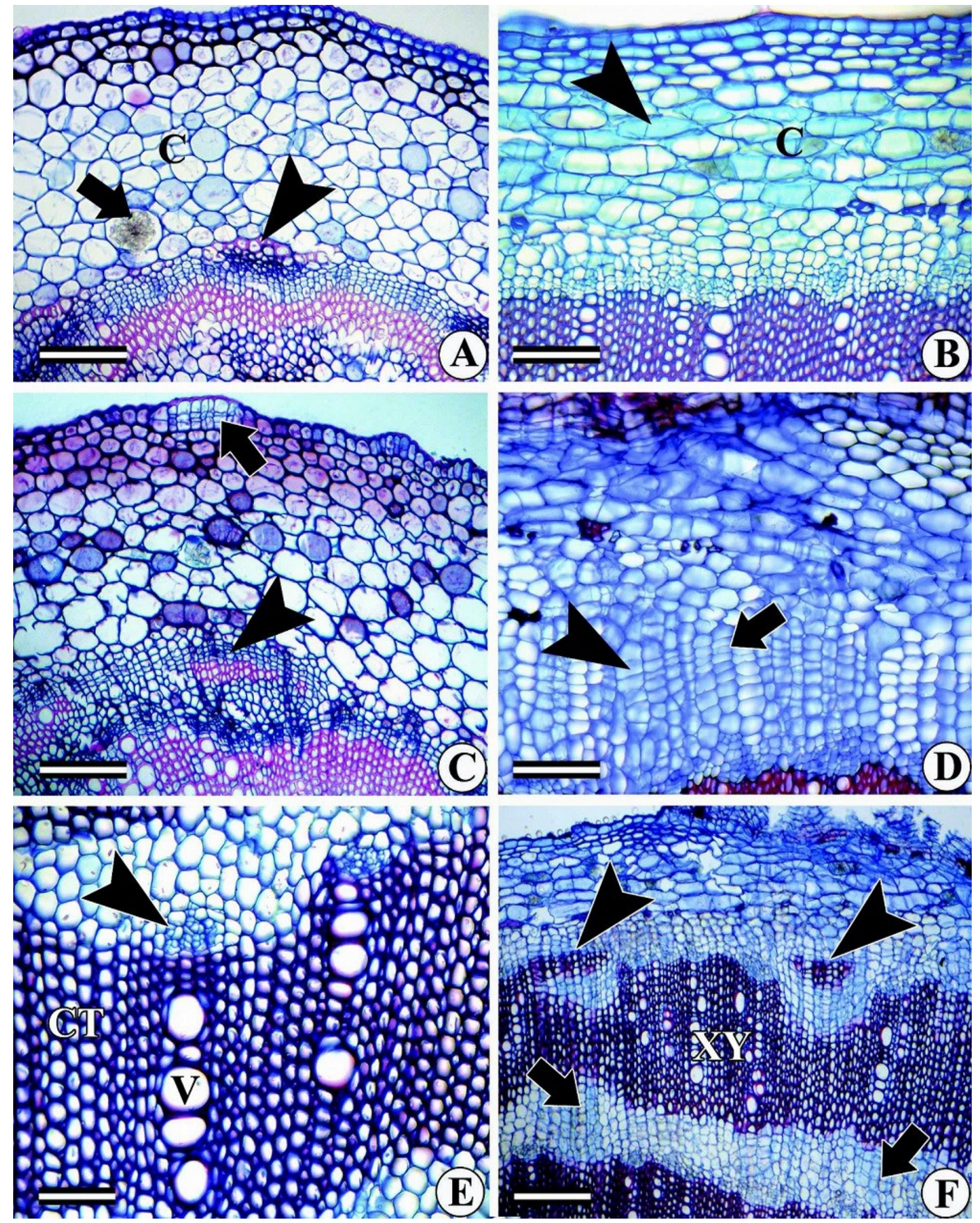

Fig. 1 A-F: Transverse view of young and mature stems of different species showing structure of stem and initiation of successive cambia. A: Structure of young stem showing epidermis, cortex (C); arrow showing druse in one of the cortical parenchyma cells in Gomphrena celosioides. Arrowhead indicates pericyclic fiber. B: Relatively young stem of Alternanthera betzvikiana showing structure of cortex (C). Note the tangentially flat cortical parenchyma cells (arrowhead). C: Newly initiated segment of first successive cambium (arrowhead) in Gomphrena celosioides. Note the divisions in the initiation of cork cambium (arrow). D: Initiation of successive cambium (arrow) in Aerva sanguinolentana. Note the swelling of cells prior to periclinal divisions (arrowheads). E: Phloem island (arrowhead) surrounded with thin walled conjunctive tissue (arrowhead) in Telanthera ficoidea. Abbreviations: $\mathrm{V}=$ vessel, $\mathrm{CT}=$ conjunctive tissue. F: Successive rings of xylem (XY), tangential bands of conjunctive tissues (arrows) and newly initiated cambium segment (arrowheads) in Aerva lanata. Scale bar: A-D = $100 \mu \mathrm{m} ; \mathrm{E}, \mathrm{F}=200 \mu \mathrm{m}$. 
(Tertiary Butyl Alcohol) series and embedded in paraffin wax (21). Thick stem samples were directly sectioned on the sliding microtome. Transverse, radial and tangential longitudinal sections of 15-20 $\mu \mathrm{m}$ thick were obtained with rotary (Leica RM 2035) and sliding (Leica SM2010R) microtome. Sections were stained with safranin-astra blue (22) and mounted in Dibutyl Phthalate Xylene (DPX) after dehydration through ethanol-xylene series. Temporary preparations of tangential sections were also prepared by staining with 4\% aceto-carmine for nucleus staining. Microphotographs of important results were obtained using Leica DME 2000 trinocular photomicroscope attached with Leica DFC 295 firewire digital camera.

Thin slices of secondary xylem adjacent to the outermost cambial ring were macerated with Jeffery's fluid (21). After 12-24 hrs of treatment at 55 to $60^{\circ} \mathrm{C}$, these slices were gently washed with distilled water and stained with $1 \%$ aqueous safranin to measure the length of vessel elements and xylem fibres while the vessel diameter was measured directly from the transverse sections. Length of the sieve tube elements was obtained directly from the tangential longitudinal sections while their width was obtained from the transverse sections. Thirty measurements of each cell type of the secondary xylem and sieve elements were taken randomly to obtain mean and standard deviation for each cell type.

\section{Results}

Structure of young stem: The outermost layer in the young stem possess single layered polygonal epidermal cells that were covered with a thick cuticle (Fig. 1A). The epidermis was followed by relatively wider cells composing 2-3 cell layered hypodermis (Fig. 1A-C). As the secondary growth progressed further, cells beneath the epidermis underwent anticlinal and periclinal divisions to form the cork (Fig. 1C). Cortex forms the next layer and that was composed of oval to polygonal thin walled parenchyma cells of irregular size (Fig. 1A, C) in Gomphrena celosioides while in remaining species the cortex was composed of tangentially flat cells, which frequently show anticlinal divisions (Fig. 1B). Endodermis is indistinct and pericyclic fibres can be seen as isolated strands or short segments on the inner side of the cortex (Fig. $1 \mathrm{~A}, \mathrm{~B}, \mathrm{D})$. As the time passes, successive rings of cambia initiate external to the phloem produced by the regular vascular cambium (Fig. 1C, D \& F).

Structure of cambium: Stems of all the investigated species in the present study were composed of three to five successive rings of cambia (Fig. 2A-D). The cambium was solely composed of fusiform cambial initials while ray initials were found absent. The cambium is storied with relatively short fusiform cambial cells, measuring from $120-190 \mu \mathrm{m}$ in length. In transverse view, the inactive cambium appears as two to three layers of cells arranged in radial files while it was four to six layered when dividing actively and producing the secondary vascular tissues and conjunctive tissues (Fig. 1F). Production of conducting elements of secondary xylem and phloem occurs only from very few cells of the cambium while most portions of the cambial segments produced only conjunctive tissues in centripetal and centrifugal direction. Interestingly, this segment of cambium does not produce vessels internally and phloem externally.

Development of successive cambium: As a characteristic feature of Amaranthaceae, all the species investigated in the present study showed that the vascular cambium ceased to divide after producing a limited amount of secondary xylem (i.e. 500-700 $\mu \mathrm{m}$, in G. celosioides and 1-2 $\mathrm{mm}$ in rest of the species). Prior to the cessation of cell division, small segments of the cambium relatively lagged behind (Fig. 1F) and a small segment of cambium initiated outside to the ceased portion (Fig. 1F). The newly formed segment of the cambium connects them with the adjacent cambial segment and formed a complete ring. Initiation of new cambium takes place from the parenchyma cells located 3-6 cell layers outside the phloem produced by the previous cambium (Fig. 1D). At the time of new cambium initiation, one or two layers of parenchyma repeatedly divide periclinally and form radial files of 4-5 layers of meristematic cells (Fig. 1D). Out of this, cells located on the outer and inner margin of a newly formed cambium divide further and give rise to conjunctive tissues on either side of it. Interestingly, in young stems, only small segments of cambia are renewed (Fig. 2A) thus resulting into small islands of the cambial segment and phloem embedded within secondary xylem (Fig. 2A). However, subsequently, complete ring of the previous cambium is replaced with new one (Fig. 2A-D). Development of further cambia displayed similar mode of its initiation, as mentioned above. However, in aquatic species viz. A. philoxeroides, xylem formation was much less whereas the formation of successive cambia was found absent (Fig. 2E, F).

Structure and development of vascular elements: In all nine species from four genera, each cambium divides bi-directionally and produce secondary xylem in normal fashion, i.e. xylem centripetally and phloem centrifugally. The development of conducting elements of the secondary xylem and phloem remains restricted to small segments of the cambium while alternate sectors of the cambial ring produced only conjunctive elements on either side of the cambium (Fig. 1E). Development of conducting elements of secondary xylem and secondary phloem is not synchronous in all the species investigated and it was observed that it took place simultaneously in some of the segments or the 

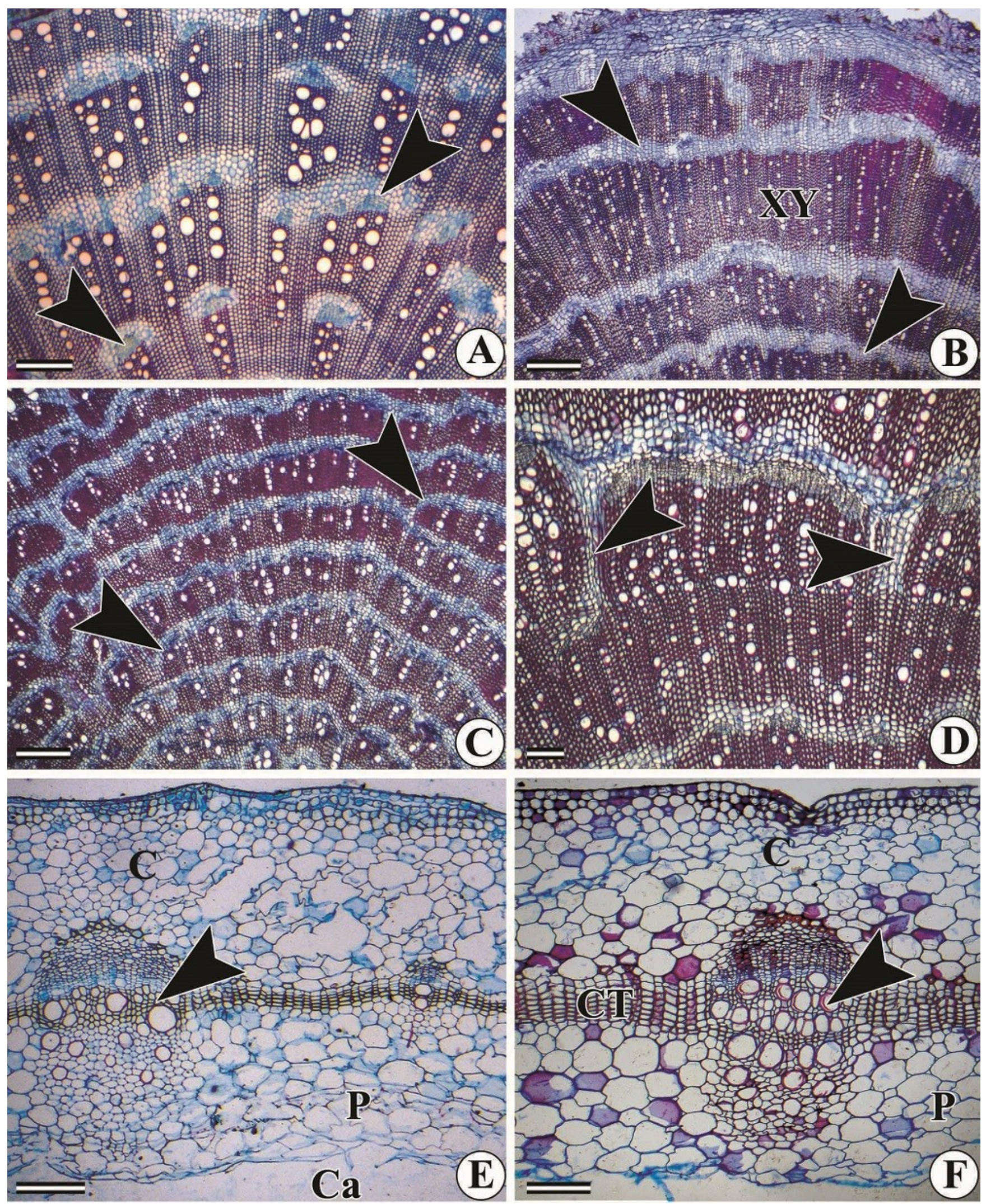

Fig. 2 A-F: Transverse view of stems of different species showing structure and composition of secondary xylem. A: Structure of the secondary xylem in Telanthera ficoidea. Note the discontinuous rings of xylem and phloem (arrowheads). B: Thick stem of Aerva lanata showing continuous successive rings of xylem (XY) alternating with conjunctive tissues enclosing phloem (arrowheads). C: Thick stem of Aerva javanica showing successive xylem rings that forms anastomosing (arrowheads). Abbreviations: XY = xylem. D: Structure of secondary xylem in Aerva sanguinolentana. Note the radial plates of parenchyma cells (arrowheads). E \& F: Structure and composition of stem in Alternanthera philoxeroides (aquatic species) showing cortex (C), secondary xylem (arrowhead), pith cells (P) and part of cavity (Ca) at the place of pith. Abbreviation: $\mathrm{CT}=$ conjunctive tissue. Scale bar: $\mathrm{A}-\mathrm{C}=500 \mu \mathrm{m} ; \mathrm{D}-\mathrm{F}=200 \mu \mathrm{m}$.

development of lignified elements precedes that of phloem. Development of conducting elements of secondary xylem and phloem remains restricted to a small portion of cambium (Fig. 1E) while the rest 
of the segments exclusively produces thick walled conjunctive tissues (Fig. 2A).

Thick stems of all nine species investigated were composed of 3-10 successive rings of xylem alternating with phloem except $A$. philoxeroides (Fig. 2A-C). The xylem is composed of vessel elements, tracheids, axial parenchyma, and fibres while xylem rays are absent (Fig. 3A). Vessels are oval to circular in outline (Fig. 2A-D) with alternate bordered pits on their lateral walls and possess simple perforation plate on a slightly oblique to transverse end walls (Fig. 3A-D). Vessels may be solitary or in radial multiples of two to four. The length of vessel elements varies from 129-168 $\mu \mathrm{m}$ in G. celosioides and 158-176 $\mu \mathrm{m}$ in T. ficoidea, while no much variation was observed in other species. Similarly, the width of the vessel diameter showed no much variation and ranged from 59-79 $\mu \mathrm{m}$. In all the species investigated, fibers were non-septate with simple pits on their radial walls and retain nuclei even after deposition of lignin. The length of fibres was measured from 580-746 $\mu \mathrm{m}$ while their width ranged from 18-22 $\mu \mathrm{m}$. Fibres were nucleated, and the nuclei were oval to oblong in recently formed fibres while they were fusiform shaped in the fibres differentiated at the beginning of secondary growth. Fibres also showed accumulation of starch in the lumen in all species investigated. As the secondary growth progressed further, the rayless secondary xylem observed in the early stage of secondary growth (Fig. 3A) showed the formation of rays (Fig. 3B-D). Some of the axial parenchyma divide transversely and lead to the formation of cells like heterocellular rays with vertically upright cells (Fig. 3B) in species like Aerva javanica and Telanthera ficoidea while in other species like Aerva sanguinolentana, and Alternanthera bettzickiana axial parenchyma cells were arranged in such a way that they appear like rays (Fig. 3C, D).

\section{Discussion}

The occurrence of medullary bundles in some members and pattern of secondary growth in Amaranthaceae, Nyctaginaceae, and Chenopodiaceae has always kept these families highlighting in the literature since several years. Therefore, various opinions have been expressed by earlier researchers on nature of the meristem $(4,7,23-27)$ and more than 65 terminologies (11) have been proposed to this unique nature of meristem that is responsible for the secondary growth. As documented by earlier researchers for Amaranthaceae, initiation of successive cambia in species investigated here occurs from the parenchyma cells positioned outside to the phloem produced by the previous cambium $(4,7,18,24,25)$. Though, the occurrence of successive cambia is reported earlier in several species of Amaranthaceae, information on the specimen investigated here are either partial (7) or lacking completely as in case of Alternanthera bettzickiana and $A$. philoxeroides.

After a short period of normal secondary growth, the small segments of the first (normal) ring of vascular cambium ceased to divide and a new segment of cambium replaced the nondividing segment of the cambium. Formation of new cambium in the similar pattern has been reported in Amaranthaceae by earlier researchers $(4,7,18,24,25,28,29)$ which develops from the parenchyma cells positioned outside to the phloem formed by the former cambium. Development of conducting elements of secondary xylem and phloem remains restricted to small alternating segments while the rest of the alternating segments produce only conjunctive elements. Such behaviour of cambium has been reported in several species of Amaranthaceae and its allied families $(9,16)$. Production of secondary xylem and phloem by small cambial segment and production of conjunctive tissue by alternating segment is correlated with master cambium $(9,16)$.

The occurrence of rayless condition in the secondary xylem is unusual in dicots $(15,18,26-30)$. The absence of rays in the xylem is correlated with plants that have lost normal cambial activity during the evolution leading towards herbaceous nature (31). It appears factual that all nine species investigated here are herbaceous, in which the selective value for rays is minimal $(15,31,32)$. Gibson (33) has also inferred that the absence of rays is common in most dicotyledons that show reduced cambial activity and short fusiform initials. Structure of secondary xylem in Gomphrena globosa and G. celosioides has been reported earlier (7) but detailed information on the development of successive cambia and structure of secondary xylem is partial and lacking the details.

Though in the initial stages of secondary growth, the xylem in transverse view appears uniform with no rays, but in thick stems rays like radially arranged cells can be observed. When these radially arranged cells were observed in tangential view, they appear like storied parenchyma. Similar, observations have also been documented by Heklau et al. (20) and referred them as radial strips of axial parenchyma.

In all nine species, rays are found to be absent in the early stage of secondary growth. The occurrence of nucleated xylem fibres in Amaranthaceae and other families is reported earlier in some species $(7,29,34,35)$. All the species investigated here showed the presence of nucleated xylem fibres, and it is said to be an adaptive feature performing a dual function like mechanical support and storage cells. Starch deposition in fibre lumen also suggests their role as a reservoir of photosynthetic products. 

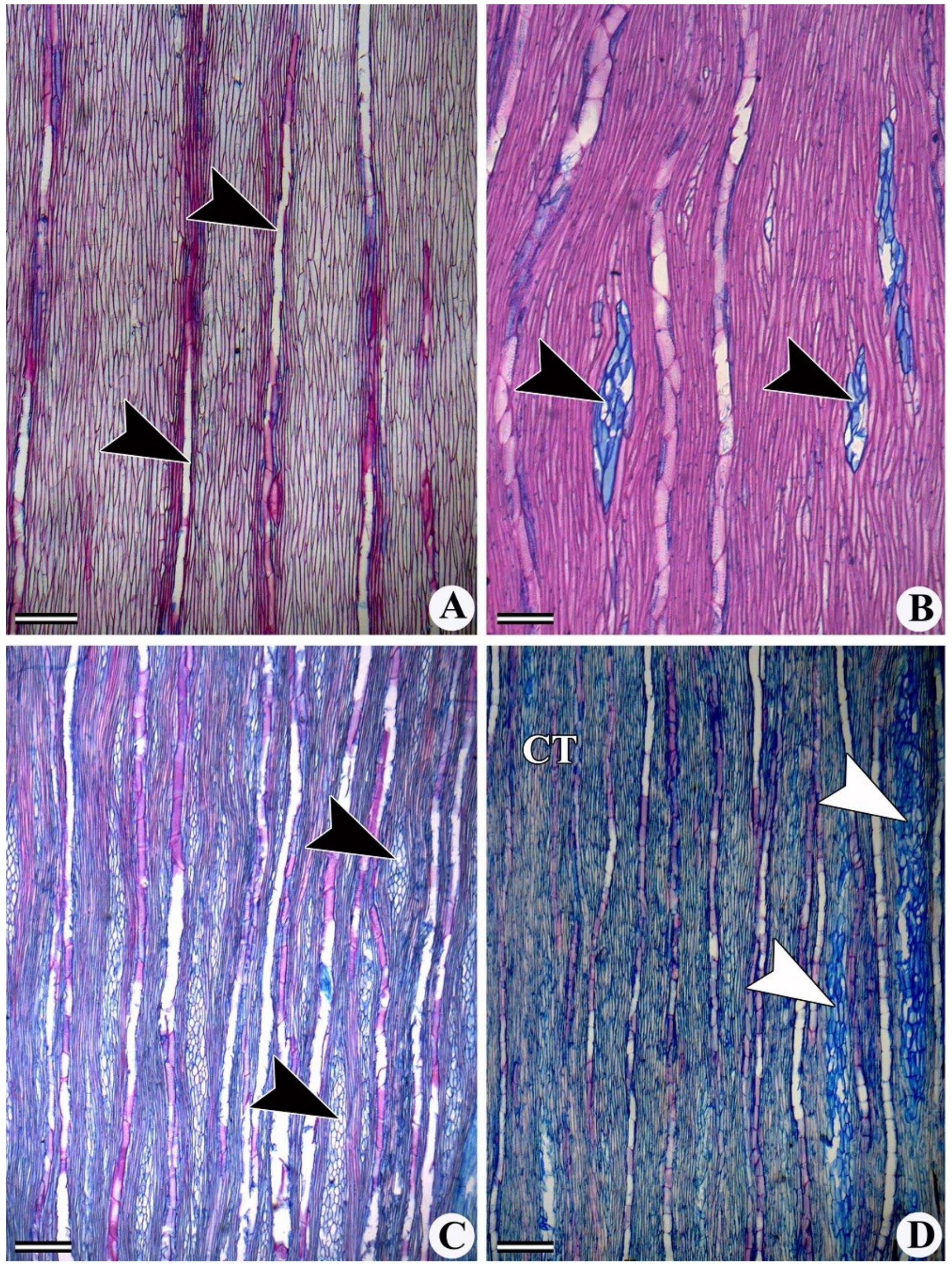

Fig. 3 A-D: Longitudinal view of the stems showing composition of secondary xylem in different species. A: Gomphrena globosa showing rayless xylem. Arrowheads indicate vessels. B: Rays (arrowheads) in Aerva sanguinolentana. C: Typical vascular rays (arrowheads) formed in the thick stems of Aerva javanica. D: Tall vascular rays with vertically upright cells intermixed with small ray cells in Aerva javanica. Abbreviation: $\mathrm{CT}=$ conjunctive tissue. Scale bar: A $=500 \mu \mathrm{m} ; \mathrm{B}-\mathrm{D}=200 \mu \mathrm{m}$. 
In conclusion, successive cambia in different species of the Amaranthaceae develop from the parenchyma cells located external to the phloem formed by the regular vascular cambium. In the early stages of secondary growth rays may be absent, but as the stem thickness increases, rays may develop.

\section{Acknowledgements}

Authors are thankful to anonymous reviewers for valuable suggestions on previous version of the manuscript. Thanks are also due to the Prof. G. Sandhya Kiran (Head, Dept. of Botany, Faculty of Science, The Maharaja Sayajirao University of Baroda), Department of Science and Technology, Government of India (GOI) and University Grants Commission, GOI for financial support under FIST and DRS programm respectively.

\section{Competing interests}

The authors declared that they have no competing interest.

\section{Authors' contributions}

ADG and RAS collected the specimens from the field and wrote the initial draft of the manuscript, DGR and RAS prepared the slides and analysed the data, KSR supervised the project. Revision of the manuscript is done by ADG and KSR. All the authors approved the final manuscript.

\section{References}

1. De Bary A. Comparative anatomy of the vegetative organs of the phanerogams and ferns (translated by Bower FO and Scott DH). The Clerondon Press, Oxford. 1884; p 693.

2. Wilson CL. Medullary bundles in relation to the primary vascular system in Chenopodiaceae and Amaranthaceae. Bot Gaz. 1924; 78:175-99.

3. 3. Schinz H. Amaranthaceae. In: Engler A, Prantle K. (Eds) Die naturlichen Pflanzenfamilien. Vol 1a. Engelmann, Leipzig. 1925; pp 91-118.

4. Balfour ENA. Anomalous secondary thickening in Chenopodiaceae, Nyctaginaceae and Amaranthaceae. Phytomorph. 1965; 15:111-22.

5. Stevenson DW, Popham RA. Ontogeny of the primary thickening meristem in seedlings of Bougainvillea spectabilis. Amer J Bot. 1973; 60: 1-9.

6. DeMason DA. The primary thickening meristem: definition and function in monocotyledons. Amer J Bot. 1983; 70:955-962.

7. Rajput KS. Stem anatomy of Amaranthaceae: Rayless nature of xylem. Flora 2002; 197: 224-32. https://doi.org/10.1078/0367-2530-00033

8. Carlquist S. Wood and stem anatomy of woody Amaranthaceae s.s.: ecology, systematics and the problem of defining rays in dicotyledons. Bot J Lin
Soc. 2003;143:1-19. https://doi.org/10.1046/j.10958339.2003.00197.x

9. Carlquist S. Successive cambia in Aizoaceae: products and process. Bot J Lin Soc. 2007a; 154:141-55. https://doi.org/10.1111/j.1095-8339.2007.00593.x

10. Carlquist S. Successive cambia revisited: ontogeny, histology, diversity and functional significance. J Torr Bot Soc. 2007b; 134:301-32.

11. Yarrow GL, Popham RA. The ontogeny of primary thickening meristem of Atriplex hortensis L. (Chenopodiaceae). Amer J Bot. 1981; 86:1042-1049.

12. Mao TL. Etude comparative des caracteres anatomiques et du parcous des faisceaux liberoligneux des Chenopodiacees et des Amarantaceae. Ph.D. Thesis, Paris. 1933.

13. Menezes NL, Silva DC, Arruda RCO, Melo de Pinna GF, Cardoso VA, Castro NM, Scatena VL, Scremindias E. Meristematic activity of the endodermis and the pericycle in the primary thickening in monocotyledons. Considerations on the "PTM". Anais da Academia Brasileira de Ciencias. 2005; 77:259-274. https://doi.org/S0001-37652005000200006

14. Carlquist S. Wood and stem anatomy of Stegnosperma (Caryophyllales); phylogenetic relationships; nature of lateral meristems and successive cambial activity. IAWA Journal. 1999; 20(2):149-63.

15. Carlquist S. Comparative Wood Anatomy, Systematic Ecological and Evolutionary Aspect of Dicotyledonous Wood. New York: Springer-Verlag. 2001; p.204.

16. Carlquist S. Lateral meristem, successive cambia and their products: a reinterpretation based on roots and stems of Nyctaginaceae. Bot J Linn Soc. 2004; 146:129 43. https://doi.org/10.1111/j.1095-8339.2004.00324.x

17. Timonin AK. Anomalous secondary thickening of the axial organs of the centrospermae (Based on the examples of Amaranthaceae Juss.). 1. The concept of thickening pattern in some species. Byull Mosk Obshch Ispyt Prir Otdel Biol. 1987; 92:63-81.

18. Rajput KS, Rao KS. Structural and development studies on cambial variant in Pupalia lappacea (L). Juss. (Amaranthaceae). Ann Bot Fennici. 1999a; $36: 137-41$.

19. Rajput KS, Rao KS. Secondary growth in the stem of some species Alternanthera and Achyranthes aspera (Amaranthaceae). IAWA J. 2000; 21:417-24. https://doi.org/10.1163/22941932-90000257

20. Heklau H, Gasson P, Schweingruber F, Baas P. Wood anatomy of Chenopodiaceae (Amaranthaceae s.l.). IAWA J. 2012; 33:205-232. https://doi.org/10.1163/22941932-90000090

21. Berlyn GP, Miksche JP. Microtechnique and Cytochemistry. Iowa St Univ Press Ames Iowa. 1976; p.326.

22. Srebotnik E, Messener K. A simple method that uses differential staining and light microscopy to assess the selectivity of wood delignification by white rot fungi. Appl Environ Microbiol. 1994; 60:1383-86.

23. Philipson WR, Ward JM. The ontogeny of vascular cambium in the stem of seed plants. Biol Rev. 1965; 40:534-79.

24. Baird WV, Blackwell WH. Secondary growth in the axis of Halogeton glomeratus (Beib) Meyer (Chenopodiaceae). Bot Gaz. 1980; 141:269-76. 
25. Fahn A, Zimmermann MH. Development of successive cambia in Atriplex halimus (Chenopodiaceae). Bot Gaz. 1982; 143:353-57.

26. Rajput KS. Structure of cambium and its derivatives in the compressed stem of Canavalia ensiformis (L.) DC (Fabaceae). Phyton Horn. 2003; 43:135-46.

27. Rajput KS, Marcati CR. Stem anatomy and development of successive cambia in Hebanthe eriantha (Poir.) Pedersen: a neotropical climbing species of the Amaranthaceae. Plant Syst Evol. 2013; 299:1449-59. https://doi.org/10.1007/s00606-013-0807-9

28. Zhang $\mathrm{H} \mathrm{Hu} \mathrm{Z}$. Anomalous secondary thickening in the roots of medicinal species of Cyathula officinalis Kaun. J. Wuhan Bot Res. 1989; 7:21-26.

29. Rajput KS, Rao KS. Nucleated xylem fibres in some Indian herbaceous species. Israel J Plt Sci. 1999b; 40:265-268.
30. Rao KS, Rajput KS. Rayless secondary xylem of Trianthema monogyna (Aizoaceae). Phyton Horn. 1998; 37:161-66.

31. Carlquist S. Comparative wood anatomy, systematic ecological and evolutionary aspect of dicotyledonous wood. Spr Verlag Heidelberg Berlin New York. 1988; p.384.

32. Rajput KS. Secondary growth of the stem of Celosia argentea L. and Aerva sanguinolenta (L.) Blume (Amaranthaceae). Phyton Horn 2001; 41:169-177.

33. Gibson AC. Rayless secondary xylem of Halophytum. Bull Torrey Bot Club. 1978; 105:39-44.

34. Fahn A, Leshem B. Wood fibres with living protoplasts. New Phytol. 1963; 62:91-98.

35. Rajput KS, Rao KS. Nucleated xylem fibres in some members of Combretaceae. IAWA J. 1999a; 20:79-83. 